\title{
Dietary phosphorus requirement of pejerrey fingerlings (Odontesthes bonariensis)
}

\author{
Cleber Bastos Rocha', Mauro Kaster Portelinha' ${ }^{1}$, João Morato Fernandes ${ }^{1}$, Aline Conceição \\ Pfaff de Britto ${ }^{1}$, Sérgio Renato Noguez Piedras ${ }^{1}$, Juvêncio Luís Osório Fernandes Pouey ${ }^{1}$
}

${ }^{1}$ Programa de Pós-Graduação em Zootecnia, Departamento de Zootecnia, Universidade Federal de Pelotas, Pelotas, RS, Brasil.

\begin{abstract}
To determine the available phosphorus requirement of pejerrey fish, four semi-purified diets were formulated to contain increasing available phosphorus levels $(0.90,2.7,5.7$ and $8.3 \mathrm{~g} / \mathrm{kg})$. Each diet was assigned to groups of 10 fish with average weight of $1.26 \pm 0.17 \mathrm{~g}$, distributed into a completely randomized design with four treatments and four replications. Fish were fed at a rate of $10 \%$ total biomass four times a day for 60 days. The parameters productive performance, body chemical composition and mineral composition of bones and scales were evaluated. The best productive performance of fingerlings was obtained with the diet containing $4.3 \mathrm{~g} / \mathrm{kg}$ available phosphorus. The average level of $6.3 \mathrm{~g} / \mathrm{kg}$ available phosphorus promotes better mineralization of bones and scales in pejerrey fish.
\end{abstract}

Key Words: bone, fish, food, growth, mineral, nutrition

\section{Introduction}

Phosphorus is one of the most important minerals for fish growth, bone mineralization and lipid and carbohydrate metabolism (Sales and Janssens, 2003; NRC, 2011). However, the phosphorus availability from plant sources is usually low and varies according to the fish species (Boscolo et al., 2005). This occurs because, in cereal grains, phosphorus is in the form of phytic acid, unavailable for monogastrics (Vielma et al., 2002; Raboy, 2009).

Fish in their habitat easily meet their nutritional requirements through the available food in the environment. However, when farmed intensively, their needs have to be met via the diet (Miranda et al., 2000).

Increased fish cultures require the formulation of balanced diets because artificial feed is the only source of nutrition for fish; furthermore, aquaculture effluents high in phosphorus levels contribute to the pollution of the aquatic ecosystem and, eventually, cause eutrophication of natural fresh waters (Coloso et al., 2003; Pezzato et al., 2006).

The pejerrey (Odontesthes bonariensis; Valenciennes [Atheriniformes, Atherinopsidae]) is a native species from Southern Brazil distributed over numerous water bodies around the world (Kopprio et al., 2010).

For most cultivated fish species, phosphorus requirements range from 3 to $15 \mathrm{~g} / \mathrm{kg}$ of diet (NRC, 2011). However, the phosphorus requirements for pejerrey Odontesthes bonariensis have not been determined. Thus, this study was undertaken to determine the dietary phosphorus requirements for pejerrey fingerlings fed semipurified diets.

\section{Material and Methods}

The experimental diets were formulated according to the recommendation for the species (Piedras et al., 2004) to contain $550 \mathrm{~g} / \mathrm{kg}$ crude protein and 3,200 kcal/ $\mathrm{kg}$ digestible energy. For obtaining a basal diet with low levels of phosphorus, albumin ( $800 \mathrm{~g} / \mathrm{kg}$ crude protein) containing $1.72 \mathrm{~g} / \mathrm{kg}$ total phosphorus was used as protein source. The different levels of total phosphorus $(0.9,2.7,5.7$ and $8.3 \mathrm{~g} / \mathrm{kg})$ were obtained by adding sodium phosphate monobasic p.a. to the basal diet at levels of zero (control), 9.0, 22.0 and $35.0 \mathrm{~g} / \mathrm{kg}$. The quantity of calcium was about $7 \mathrm{~g} / \mathrm{kg}$ of the diet (NRC, 2011) by adding calcium carbonate PA (Table 1).

The ingredients were weighed and mixed gradually from low to high volume to facilitate homogenization. After these procedures, they were mixed again in blender with addition of warm water $(100 \mathrm{~g} / \mathrm{kg})$ to facilitate their homogenization. At the end of this process the mixture was distributed into trays and oven-dried at $50{ }^{\circ} \mathrm{C}$ for approximately 14 hours. These diets were packed and stored in a freezer $\left(-18^{\circ} \mathrm{C}\right)$ for later use.

The artificial reproduction of pejerrey specimens collected in Lagoa Mangueira/RS was carried out through extrusion to obtain the sexual products (semen and oocytes) and the eggs were incubated in the laboratory. After hatching, these fish were fed zooplankton and powdered 
Table 1 - Composition $(\mathrm{g} / \mathrm{kg})$ of the experimental diets

\begin{tabular}{|c|c|c|c|c|}
\hline \multirow{2}{*}{ Ingredient } & \multicolumn{4}{|c|}{ Experimental diets (phosphorus levels g/kg) } \\
\hline & 0.90 & 2.7 & 5.7 & 8.3 \\
\hline Albumin ${ }^{1}$ & 610 & 610 & 610 & 610 \\
\hline Cellulose & 208 & 199 & 186 & 173 \\
\hline Canola oil & 35 & 35 & 35 & 35 \\
\hline Cod liver oil & 35 & 35 & 35 & 35 \\
\hline Dextrin & 30 & 30 & 30 & 30 \\
\hline Phosphorus-free vitamin/mineral mix $^{2}$ & 30 & 30 & 30 & 30 \\
\hline Gelatin & 20 & 20 & 20 & 20 \\
\hline Carboxymethyl cellulose & 20 & 20 & 20 & 20 \\
\hline Calcium carbonate & 12 & 12 & 12 & 12 \\
\hline Monobasic sodium phosphate & - & 9 & 22 & 35 \\
\hline Total & 1000 & 1000 & 1000 & 1000 \\
\hline \multicolumn{5}{|c|}{ Chemical composition (dry matter basis $\mathrm{g} / \mathrm{kg}$ ) } \\
\hline Digestible energy $(\mathrm{Kcal} / \mathrm{kg})^{3}$ & 3,246 & 3,246 & 3,256 & 3,256 \\
\hline Crude protein & 560.2 & 560.6 & 570.7 & 571.3 \\
\hline Ether extract & 162.7 & 161.8 & 156.9 & 167.0 \\
\hline Dry matter & 859.6 & 867.6 & 867.6 & 876.6 \\
\hline Ash & 65.1 & 71.8 & 77.8 & 86.3 \\
\hline Calcium & 7.0 & 7.3 & 7.4 & 7.3 \\
\hline Analyzed total phosphorus ${ }^{4}$ & 0.90 & 2.70 & 5.70 & 8.30 \\
\hline
\end{tabular}

commercial fingerling feed (550 g/kg crude protein) and kept in polypropylene box $500 \mathrm{~L}$ with recirculation until the beginning of experiment. One hundred and sixty fish with average weight of $1.26 \pm 0.17 \mathrm{~g}$ which were randomly divided into 16 boxes of polypropylene with $200 \mathrm{~L}$ in volume were selected. These experimental units had a biofilter system, artificial aeration with blower central water recirculation and air-conditioned room to maintain water temperature constant.

A completely randomized design with four treatments and four replicates was carried out. All fish were fed powdered commercial fingerling feed for 10 days for subsequent introduction of experimental diets. The feeding rate was $10 \%$ biomass distributed four times per day $(8.00 \mathrm{~h}, 10.00 \mathrm{~h}$, $14.00 \mathrm{~h}$. and $17.00 \mathrm{~h}$ ) and feed leftovers and excrements were siphoned once per day. The experimental period was 60 days. The biometrics was performed at the end by weighing and measuring the animals. The chemical composition of experimental diets was obtained through chemical analysis (AOAC, 1995) and mineral analysis through atomic absorption spectrophotometry. At the beginning of the experimental period 30 fish were euthanized with benzocaine $(300 \mathrm{mg} / \mathrm{L})$ and frozen $\left(-18^{\circ} \mathrm{C}\right)$ to evaluate body chemical composition. At the end of the experiment the same process was performed to all fish. To determine the mineral retention of scales, three animals from each replicate were peeled by scraping with a scalpel blade and the scales were dried at $50^{\circ} \mathrm{C}$. The spinal bones were kept in warm water $\left(80^{\circ} \mathrm{C}\right)$ for two minutes and then immediately dissected with tweezers (Furuya et al., 2001). These samples were digested in acid solution (Silva and Queiroz, 2004) and the concentrations of $\mathrm{P}$ and $\mathrm{Ca}$ were determined in triplicate through atomic absorption spectrophotometry (Tedesco et al., 1995).

The body composition analysis of crude protein, ether extract, ash and moisture was performed using three fish per replicate according to the AOAC (1995). Water quality parameters of dissolved oxygen and temperature (YSI model 55 digital oximeter), $\mathrm{pH}$ (AT 310 model potentiometer), total phosphorus (AT-100P model photocolorimeter), alkalinity and total ammonia were monitored three times a week, following the method suggested by APHA (1998).

The fish performance was evaluated using the following formulae: weight gain $(\mathrm{g})=$ final weight $(\mathrm{g})$ - initial weight $(\mathrm{g})$; specific growth rate $(\%$ body weight/day $)=[(\ln$ final weight $-\ln$ initial weight)/days of experiment] $\times 100$; apparent feed conversion ratio $=($ feed supplied $/$ weight gain $) \times 100$; and survival $(\%)=[$ number of fish at the end of the experiment/number of fish at the beginning of the experiment] $\times 100$.

Data were subjected to analysis of variance (ANOVA) and regression analysis (Statistica, version 5.0). 


\section{Results and Discussion}

The physicochemical parameters of the water remained appropriate for the species (Miranda et al., 2006) showing no difference between treatments with the following mean results: temperature $24.78 \pm 2.2{ }^{\circ} \mathrm{C}$, dissolved oxygen $4.85 \pm 0.58 \mathrm{mg} / \mathrm{L}, \mathrm{pH} 7.8 \pm 0.20$, total ammonia nitrogen $0.03 \pm 0.0 \mathrm{mg} / \mathrm{L}$, total phosphorus $0.30 \pm 0.12 \mathrm{mg} / \mathrm{L}$ and total alkalinity $45 \pm 5 \mathrm{mg} / \mathrm{L}$.

The weight gain showed quadratic effect with increasing levels of dietary phosphorus. By the fit curve from the equation of regression polynomial, it could be observed that $4.3 \mathrm{~g} / \mathrm{kg}$ phosphorus result in increased weight gain (Table 2), similar to that recommended by Wilson et al. (1982) for channel catfish (Ictalurus punctatus). For juvenile black seabream (Sparus macrocephalus) the phosphorus requirements of greatest weight gain were $5.5 \mathrm{~g} / \mathrm{kg}$ (Shao et al., 2008).

A quadratic effect of phosphorus levels on total length, specific growth rate and apparent feed conversion, which were even better until $4.3 \mathrm{~g} / \mathrm{kg}$ phosphorus in the diet, were observed. For juvenile Nile tilapia (Oreochromis niloticus), Furuya et al. (2008) observed quadratic effect of phosphorus levels on feed conversion, with best level at $4.8 \mathrm{~g} / \mathrm{kg}$.
Kim et al. (1998) recommend $7 \mathrm{~g} / \mathrm{kg}$ available phosphorus for the greatest weight gain of mirror carp (Cyprinus carpio). Ye et al. (2006) evaluated the effect of supplementation with calcium and phosphorus on a purified $\operatorname{diet}(3 \mathrm{~g} / \mathrm{kg} \mathrm{Ca}$ and $4 \mathrm{~g} / \mathrm{kg} \mathrm{P}$ ) for juvenile grouper (Epinephelus coioides), verifying that only phosphorus supplementation $(6 \mathrm{~g} / \mathrm{kg})$ influenced the weight gain. Survival was not affected by dietary phosphorus levels $(\mathrm{P}>0.05)$.

Fontagné et al. (2009) found in a radiographic study that rainbow trout (Oncorhynchus mykiss) fingerlings fed a diet deficient in phosphorus $(5 \mathrm{~g} / \mathrm{kg}$ total phosphorus or zero available phosphorus) showed high incidence of vertebral abnormalities.

The body composition of crude protein and moisture were not affected $(\mathrm{P}>0.05)$ by dietary phosphorus levels (Table 3); this result was observed by Lellis et al. (2004) for rainbow trout.

Increased phosphorus levels in the diet reduced body ether extract linearly. The same was observed by Mai et al. (2006), who evaluated the requirements of available phosphorus for yellow croaker (Pseudosciaena crocea) and Zhang et al. (2006), for Japanese sea bass (Lateolabrax japonicus). The increase in available phosphorus probably favored the energy metabolism of fatty acids ( $\beta$-oxidation),

Table 2 - Performance of pejerrey fingerlings (Odontesthes bonariensis) fed increasing levels of dietary phosphorus

\begin{tabular}{|c|c|c|c|c|c|}
\hline \multirow{2}{*}{ Variable } & \multicolumn{4}{|c|}{ Available phosphorus levels dietary (g/kg) } & \multirow{2}{*}{ Effect } \\
\hline & 0.9 & 2.7 & 5.7 & 8.3 & \\
\hline Weight gain $(\mathrm{g})$ & $0.48 \pm 0.06$ & $0.74 \pm 0.08$ & $0.65 \pm 0.06$ & $0.47 \pm 0.11$ & Quadratic \\
\hline Total length $(\mathrm{cm})$ & $6.75 \pm 0.15$ & $6.99 \pm 0.10$ & $7.09 \pm 0.12$ & $6.59 \pm 0.04$ & Quadratic \\
\hline Specific growth rate $(\mathrm{g} / 100 \mathrm{~g})$ & $0.54 \pm 0.06$ & $0.77 \pm 0.07$ & $0.69 \pm 0.05$ & $0.53 \pm 0.11$ & Quadratic \\
\hline Apparent feed conversion & $4.71 \pm 0.61$ & $3.06 \pm 0.32$ & $3.51 \pm 0.37$ & $5.03 \pm 1.37$ & Quadratic \\
\hline \multirow[t]{2}{*}{ Survival (\%) } & $70 \pm 21.60$ & $85 \pm 12.90$ & $92 \pm 9.57$ & $92 \pm 9.57$ & NS \\
\hline & \multicolumn{4}{|c|}{ Equation } & P-value \\
\hline Weight gain (g) & \multicolumn{4}{|c|}{$y=0.39+1.56 x-1.789 x^{2}, R^{2}=0.58$} & 0.002 \\
\hline Total length $(\mathrm{cm})$ & \multicolumn{4}{|c|}{$y=6.49+2.86 x-3.29 x^{2}, R^{2}=0.78$} & 0.001 \\
\hline Specific growth rate $(\mathrm{g} / 100 \mathrm{~g})$ & \multicolumn{4}{|c|}{$y=0.45 x+1.41 x-1.62 x^{2}, R^{2}=0.59$} & 0.002 \\
\hline Apparent feed conversion & \multicolumn{4}{|c|}{$y=5.49-11.45 x+13.25 x^{2}, R^{2}=0.54$} & 0.012 \\
\hline
\end{tabular}

Quadratic effect: $\mathrm{P} \leq 0.05$.

NS - not significant.

Table 3 - Body composition of pejerrey fingerlings (Odontesthes bonariensis) fed different phosphorus levels in a semi-purified diet

\begin{tabular}{|c|c|c|c|c|c|c|}
\hline \multirow{2}{*}{ Body composition (g/kg) } & \multirow{2}{*}{ Initial } & \multicolumn{4}{|c|}{ Dietary available phosphorus levels (g/kg) } & \multirow{2}{*}{ Effect } \\
\hline & & 0.9 & 2.7 & 5.7 & 8.3 & \\
\hline Crude protein & $160.1 \pm 0.37$ & $161.2 \pm 1.00$ & $159.3 \pm 0.48$ & $156.4 \pm 1.55$ & $162.7 \pm 0.45$ & NS \\
\hline Ether extract & $38.2 \pm 0.76$ & $51.6 \pm 0.59$ & $43.2 \pm 0.09$ & $40.7 \pm 0.34$ & $34.7 \pm 0.46$ & Linear \\
\hline Moisture & $745.1 \pm 1.29$ & $720.0 \pm 2.87$ & $728.8 \pm 1.15$ & $731.1 \pm 1.25$ & $724.9 \pm 1.41$ & NS \\
\hline \multirow[t]{2}{*}{ Ash } & $30.1 \pm 0.002$ & $38.6 \pm 0.002$ & $38.4 \pm 0.010$ & $42.5 \pm 0.030$ & $42.9 \pm 0.016$ & Linear \\
\hline & & \multicolumn{4}{|c|}{ Equation } & P-value \\
\hline Ether extract & & \multicolumn{4}{|c|}{$y=18.56-7.8365 x, R^{2}=0.69$} & 0.009 \\
\hline Ash & & \multicolumn{4}{|c|}{$y=13.61+2.8304 x, R^{2}=0.82$} & 0.001 \\
\hline
\end{tabular}

Number of samples $(\mathrm{n}=3)$.

Linear effect: $\mathrm{P} \leq 0.05$.

NS - not significant. 
causing a beneficial effect which is the body fat reduction enabling the production of leaner carcasses (Roy and Lall, 2003). This result differs from that observed by Ribeiro et al. (2006), who found no difference in levels of total phosphorus on the deposition of fat, calcium and phosphorus in juvenile Nile tilapia. The body ash increased linearly with increasing levels of phosphorus in the diet; this fact highlights the largest mineral deposition in bones (Figure 1). The same was found by Ye et al. (2006) for juvenile grouper.

The levels of $\mathrm{Ca}$ and $\mathrm{P}$ in the vertebrae increased quadratically with increasing levels of phosphorus in the diet (Figure 1). These results are similar to those obtained for other species such as Atlantic salmon (Salmo salar) (Vielma and Lall, 1998), rainbow trout (Bureau and Cho, 1999) and yellow croaker, (Mai et al., 2006). According to Lall and Lewis-McCrea (2007), calcium and phosphorus are closely related to skeletal development and maintenance and vertebrae mineralization.

Dietary phosphorus requirements of pejerrey based on the $\mathrm{Ca}$ and $\mathrm{P}$ concentrations in the vertebrae were calculated at $6.3 \mathrm{~g} / \mathrm{kg}$ (Figure 1). Yang et al. (2006) found similar effect for silver perch fingerlings (Bidyanus bidyanus), and minerals gradually increased up to the level of $7.2 \mathrm{~g} / \mathrm{kg}$. For juvenile haddock (Melanogrammus aeglefinus), $8.2 \mathrm{~g} / \mathrm{kg}$ of total phosphorus in the diet was adequate for maximum phosphorus deposition in the vertebrae (Roy and Lall, 2003).

The concentrations of $\mathrm{Ca}$ and $\mathrm{P}$ in the scales presented a similar trend to that observed in the vertebrae, with a quadratic effect (Figure 2). Phosphorus requirements in the

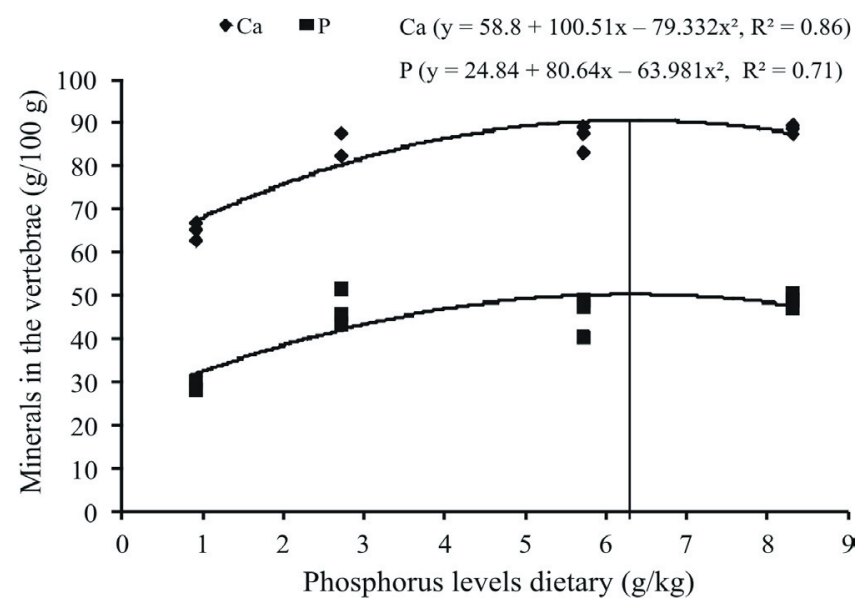

Figure 1 - Concentrations of calcium $(\mathrm{Ca})$ and phosphorus (P) in the bones of the vertebrae of pejerrey fingerlings (Odontesthes bonariensis) fed different levels of phosphorus in semi-purified diet.

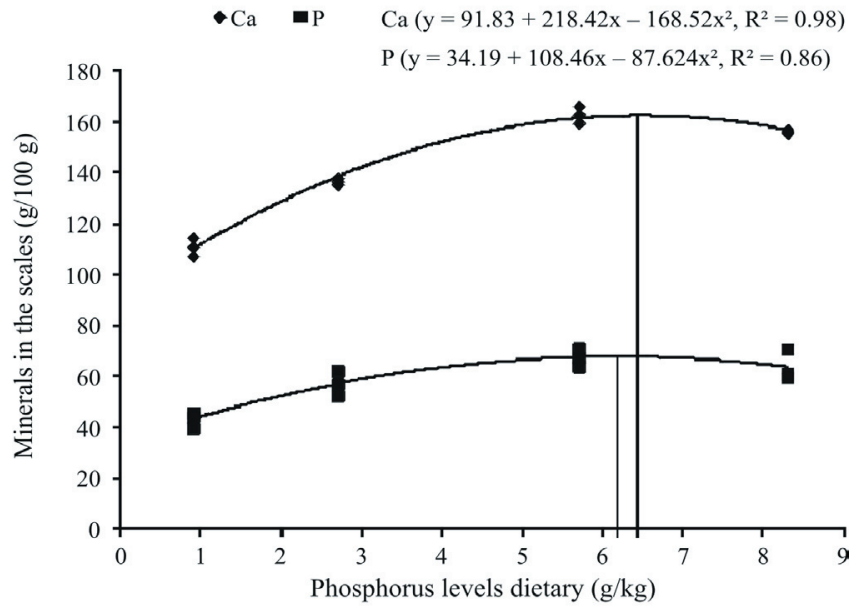

Figure 2 - Concentrations of calcium $(\mathrm{Ca})$ and phosphorus $(\mathrm{P})$ in the scales of pejerrey fingerlings (Odontesthes bonariensis) fed different levels of phosphorus in semi-purified diet

diet based on the composition of $\mathrm{Ca}$ and $\mathrm{P}$ on the scales were 6.4 and $6.1 \mathrm{~g} / \mathrm{kg}$, respectively.

Differences between the requirements of phosphorus in weight gain and maximum body mineralization can be verified in this study. Zhang et al. (2006) observed similar effects for juvenile Japanese sea bass (Lateolabrax japonicusem), whose requirement was $6.8 \mathrm{~g} / \mathrm{kg}$ for weight gain and 8.6-9.0 g/kg for bone mineralization. According to Eya and Lovell (1997), important factors such as economic, physiological and environmental factors should be considered when determining the phosphorus requirements in the diet.

\section{Conclusions}

The requirement of available phosphorus for pejerrey fingerlings is $4.3 \mathrm{~g} / \mathrm{kg}$ for best productive performance. However, for greater bone mineralization, this requirement increases to $6.3 \mathrm{~g} / \mathrm{kg}$.

\section{Acknowledgments}

The authors thank CAPES/MEC for granting the fellowship to the first author.

\section{References}

AOAC - Association of Official Analytical Chemists. 1995. Official methods of analysis. 16th ed. AOAC International, Arlington, VA, USA.

APHA - American Public Helath Association. 1998. Standard methods for examination of water and wastewater. American Public Health Association, New York.

Boscolo, W. R.; Hayashi, C.; Feiden, A.; Meurer, F. and Signor, A. 2005. Farinha de resíduos da indústria de filetagem de tilápias como fonte 
de proteína e minerais para alevinos de tilápia-do-nilo(Oreochromis niloticus). Revista Brasileira de Zootecnia 34:1425-1432.

Bureau, D. P. and Cho, C. Y. 1999. Phosphorus utilization by rainbow trout (Oncorhynchus mykiss): estimation of dissolved phosphorus waste output. Aquaculture 179:127-140.

Coloso, R. M.; King, K.; Fletcher, J. W.; Hendrix, M. A.; Subramanyam, M.; Weis, P. and Ferraris, R. P. 2003. Phosphorus utilization in rainbow trout (Oncorhynchus mykiss) fed practical diets and its consequences on effluent phosphorus levels. Aquaculture 220:801-820.

Eya, J. C. and Lovell, R. T. 1997. Available phosphorus requirements of food-size channel catfish (Ictalurus punctatus) fed practical diets in ponds. Aquaculture 154:283-291.

Fontagné, S.; Silva, N.; Bazin, D.; Ramos, A.; Aguirre, P.; Surget, A.; Abrantes, A.; Kaushik, S. J. and Power, D. M. 2009. Effects of dietary phosphorus and calcium level on growth and skeletal development in rainbow trout (Oncorhynchus mykiss) fry. Aquaculture 297:141-150.

Furuya, W. M.; Gonçalves, G. S.; Furuya, V. R. B. and Hayashi, C. 2001. Fitase na alimentação da tilápia-do-nilo (Oreochromis niloticus). Desempenho e digestibilidade. Revista Brasileira de Zootecnia 30:924-929.

Furuya, W. M.; Fujii, K. M.; Santos, L. D.; Silva, T. S. C. S.; Silva, L. C. R. S. and Michelato, M. 2008. Exigência de fósforo disponível para tilápia-do-nilo (35 a 100 g). Revista Brasileira de Zootecnia 37:961-966.

Kim, J. D.; Kim, K. S.; Song, J. S.; Lee, J. Y. and Jeong, K. S. 1998. Optimum level of dietary monocalcium phosphate based on growth and phosphorus excretion of mirror carp, Cyprinus carpio. Aquaculture 161:337-344.

Kopprio, G. A.; Freije, R. H.; Strüssmann, C. A.; Kettner, G.; Hoffmeyer, M. S.; Popovich, C. A. and Lara, R. J. 2010. Vulnerability of pejerrey Odontesthes bonariensis populations to climate change in pampean lakes of Argentina. Journal of Fish Biology 77:1856-1866.

Lall, S. P. and Lewis-Mccrea, L. M. 2007. Role of nutrients in skeletal metabolism and pathology in fish - An overview. Aquaculture 267:3-19.

Lellis, W. A.; Barrows, F. T. and Hardy, R. W. 2004. Effects of phase-feeding dietary phosphorus on survival, growth, and processing characteristics of rainbow trout Oncorhynchus mykiss. Aquaculture 242:607-616.

Mai, K.; Zhang, C.; Ai, Q.; Duan, Q.; Xu, W.; Zhang, L.; Liufu, Z. and Tan, B. 2006. Dietary phosphorus requirement of large yellow croaker, Pseudosciaena crocea R. Aquaculture 251:346-353.

Miranda, E. C.; Pezzato, A. C.; Pezzato, L. E. and Furuya, W. M. 2000. Disponibilidade aparente de fósforo em ingredientes pela tilápia-donilo (Oreochromis niloticus). Acta Scientiarum 22:669-675.

Miranda, L. A.; Bersain, G. E.; Velasco, C. A. M.; Shirojo, Y. and Somoza, G. M. 2006. Natural spawning and intensive culture of pejerrey Odontesthes bonariensis juveniles. Biocell 30:157-162.
NRC - National Research Council. 2011. Nutrient requirements of fish and shrimp. National Academy Press, Washington, D.C.

Pezzato, L. E.; Rosa, M. J. S.; Barros, M. M. and Guimarães, I. G. 2006. Exigência em fósforo disponível para alevinos de tilápia do Nilo. Ciência Rural 36:1600-1605.

Piedras, S. R. N.; Pouey, J. L. O. F. and Rutz, F. 2004. Efeitos de diferentes níveis de protein bruta e de energia digestível na dieta sobre o desempenho de alevinos de peixe-rei. Revista Brasileira de Agrociência 10:97-101.

Raboy, V. 2009. Approaches and challenges to engineering seed phytate and total phosphorus. Plant Science 177:281-296.

Ribeiro, F. B.; Lanna, E. A. T.; Bomfim, M. A. D.; Donzele, J. L.; Freitas, A. S.; Sousa, M. P. and Quadros, M. 2006. Níveis de fósforo total em dietas para alevinos de tilápia-do-nilo. Revista Brasileira de Zootecnia 35:1588-1593.

Roy, P. K. and Lall, S. P. 2003. Dietary phosphorus requirement of juvenile haddock (Melanogrammus aeglefinus L.). Aquaculture 221:451-468.

Sales, J. and Janssens, G. P. J. 2003. Nutrient requirements of ornamental fish. Aquatic Living Resources 16:533-540.

Shao, Q.; Ma, J.; Xu, Z.; Hu, W.; Xu, J. and Xie, S. 2008. Dietary phosphorus requirement of juvenile black seabream, Sparus macrocephalus. Aquaculture 277:92-100.

Silva, O. J. and Queiroz, A. C. 2004. Análise de alimentos: métodos químicos e biológicos. 3.ed. Universidade Federal de Viçosa, Viçosa, MG.

Tedesco, J. N.; Gianello, C.; Biassini, C. A.; Bohnen, H. I. and Volkweiss, S. 1995. Análises de solos, plantas e outros materiais. Departamento de Solos da Faculdade de Agronomia da Universidade Federal do Rio Grande do Sul, Porto Alegre.

Vielma, J. and Lall, S. P. 1998. Phosphorus utilization by Atlantic salmon (Salmo salar) reared in freshwater is not influenced by higher dietary calcium intake. Aquaculture 160:117-128.

Vielma, J.; Ruohonen, K. and Peisker, M. 2002. Dephytinization of two soy proteins increases phosphorus and protein utilization by rainbow trout, Oncorhynchus mykiss. Aquaculture 204:145-156.

Wilson, R. P.; Robinson, E. H.; Glatin III, D. M. and Poe, W. E. 1982. Dietary phosphorus requirement of channel catfish. Journal of Nutrition 112:1197-1202.

Yang, S. D.; Lin, T. S.; Liu, F. G. and Liou, C. H. 2006. Influence of dietary phosphorus levels on growth, metabolic response and body composition of juvenile silver perch (Bidyanus bidyanus). Fisheries Research 253:592-601.

Ye, C. X.; Liu, Y. J.; Tian, L. X.; Mai, C. S.; Du, Z. Y.; Yang, H. J. and Niu, J. 2006. Effect of dietary calcium and phosphorus on growth, feed efficiency, mineral content and body composition of juvenile grouper, Epinephelus coioides. Aquaculture 255:263-271.

Zhang, C.; Mai, K.; Ai, Q.; Zhang, W.; Duan, Q.; Tan, B.; Ma, H.; Xu, W.; Liufu, Z. and Wang, X. 2006. Dietary phosphorus requirement of juvenile Japanese seabass, Lateolabrax japonicus. Aquaculture 255:201-209. 